\title{
Biosynthesis of selenium nanoparticles using plant extracts
}

\author{
Krystyna Pyrzynska ${ }^{1}$ - Aleksandra Sentkowska²
}

Received: 4 March 2021 / Accepted: 22 July 2021 / Published online: 28 July 2021

(c) The Author(s) 2021

\begin{abstract}
Selenium nanoparticles (SeNPs) have the potential to be used for various applications. Therefore, they have attracted more attention in recent years and several synthesis methods have been exploited. Green synthesis using plant extracts has gained popularity because it requires non-toxic solvents and moderate temperatures. Furthermore, it is environmentally friendly and uses a reducing agent that is easily accessible and biodegradable. In this review, we present recent reports concerning the capability of different plant materials for the biosynthesis of selenium nanoparticles. The synthesis conditions (temperature, time, selenium precursor, and extract concentration) are discussed in combination with the characteristics of the obtained product (composition, size, shape, stability). The application of synthesized selenium nanoparticles was briefly presented.
\end{abstract}

\section{Graphic abstract}
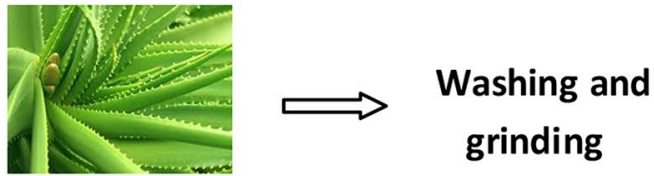

Plant`s part

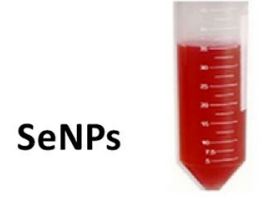

\section{Synthesis}

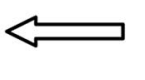

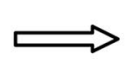

Soaking or

boiling in water

\section{Filtration}

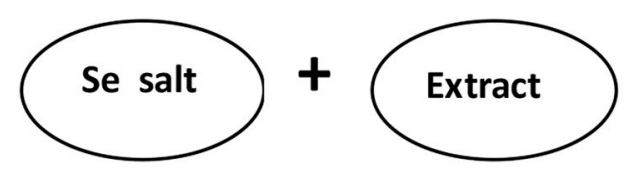

Keywords Selenium nanoparticles $\cdot$ Plant extracts $\cdot$ Green synthesis $\cdot$ Antioxidant activity $\cdot$ Applications

\section{Introduction}

In recent years, there has been growing interest in selenium due to its important function in human health $[1,2]$. Selenium plays a key role in several major metabolic pathways, such as thyroid hormone metabolism and immune functions.

Krystyna Pyrzynska

kryspyrz@chem.uw.edu.pl

1 Department of Chemistry, University of Warsaw, Pasteura 1 Str, 02-093 Warsaw, Poland

2 Heavy Ion Laboratory, University of Warsaw, Pasteura 5A, 02-093 Warsaw, Poland
It also prevents cellular damage induced by free radicals by incorporation into antioxidant enzymes. Se deficiency has been linked to a range of serious conditions such as cancer, cardiovascular and inflammatory diseases [3]. However, long-term Se supplementation or higher concentrations could cause toxicity [4]. In environmental and biological samples, selenium exists in inorganic forms, mainly as selenite $\mathrm{Se}(\mathrm{IV})$ and selenate $\mathrm{Se}(\mathrm{VI})$ ions, and as organic species with direct Se-C bonds (methylated compounds, selenoamino acids, selenoproteins, and their derivatives). Some plants have the ability to accumulate inorganic Se forms from soil and transform them into bioactive organic species [5]. The 
bioavailability and toxicity or the antioxidant and pro-oxidant effects of selenium depend on its chemical form.

Recently, nanoparticles of elemental selenium (SeNPs) have attracted attention. Their synthesis and application continue to be reported and discussed [6-11]. SeNPs differ from the properties of its corresponding bulk materials, similar to other nanoparticles. These properties as well as morphology and size depend on several parameters including a method of synthesis, use of surfactants or additives, reaction temperature, and time [11]. Moreover, their surface can be coated with surfactants and polymers [12]. The toxicity reported for SeNPs was lower in comparison to inorganic and organic forms of selenium [13].

Three main methodologies have been applied for the preparation of selenium nanoparticles covering physical, chemical, and biological methods. In the physical approach for SeNPs synthesis, pulsed laser ablation [14-16], vapour deposition [17], hydrothermal [18] and solvothermal methods [19] were used. The pulsed laser ablation method has the advantage over other methods due to the lack of contamination with chemical reagents, easy collection of NPs by centrifugation, and their high stability.

The most commonly used method for the preparation of SeNPs is a chemical reduction of inorganic selenium forms as the precursors. Ascorbic acid [20-24], glucose [24-26], fructose [27], cysteine [28, 29], glutathione [30], sodium metasulfite [31] and ionic liquid 1-ethyl-3-methylimidazolium thiocyanate [32] have been used as reducing agents, usually in the presence of stabilizing agent to prevent aggregation of nanoparticles. Water-soluble polymers [22], natural polysaccharides [22, 33], carboxymethyl cellulose [34] or bovine serum albumin [35] have been used for this purpose. However, some residuals of these chemicals limit the applications of the formed SeNPs in the pharmaceutical and medicinal areas. Yu et al. [36] synthesized different Se nanostructures, such as nanoball, nanotube, and multiarmed nanorods, by reducing $\mathrm{H}_{2} \mathrm{SeO}_{3}$ with $\mathrm{L}$-asparagine in polyethylene glycol solution. The reaction was supported by microwave irradiation at $100{ }^{\circ} \mathrm{C}$. The diameter and morphology of SeNPs were controlled by the ratio of L-asparagine/ $\mathrm{H}_{2} \mathrm{SeO}_{3}$ and the microwave irradiation time. Extending reaction time resulted in a higher diameter size of the obtained SeNPs and they were aggregated after $15 \mathrm{~min}$ of microwave treatment [36].

An alternative green approach towards the synthesis of SeNPs has been reported by using the reducing potential of various microorganisms [37]. Different groups of bacterial strains [39-44] and fungi [44-48] have the ability to reduce selenite or selenate to nano selenium as a method of detoxification. SeNPs may be formed both within the bacterial cells and/or extracellularly. All aspects of the investigations regarding the microbial transformations of selenium species could be found in the relevant reviews, where different mechanisms are discussed [37, 49-51]. The degree of control over the size and shape of SeNP is high in the chemical synthesis while using microorganisms the spherical and polydispersive SeNP with sizes in the range of $50-500 \mathrm{~nm}$ were usually obtained [37].

The utilisation of water plant extracts represents also a better alternative to chemical methods for the synthesis of selenium nanoparticles. That approach requires non-toxic solvents, mild temperatures, and application of the reducing agents that are easily accessible, cheap, biodegradable, and not harmful to the environment. It also reduces the high cost of microorganism's isolation and a final SeNPs purification, when they will be applied in biomedical sectors. Such biogenic methods of synthesis of SeNPs are becoming preferred over the conventional chemical and physical methods due to their reduced toxicity towards the environment which uses living organisms such as plants, microalgae, and other microorganisms. Selenium nanoparticles produced via the green synthesis method can be an alternative to antibiotics. SeNPs showed an antibacterial effect toward standard and antibiotic-resistant phenotypes of Gram-negative and Grampositive bacteria in a dose-dependent manner [38]. The aim of this review is to show the current knowledge concerning the plant materials' capability for the biosynthesis of selenium nanoparticles and their applications.

\section{Biosynthesis of SeNPs using plant extracts}

Several plants that have been already reported for the preparation of SeNPs are presented in Table 1 and the schematic process of their synthesis is depicted in Fig. 1. In the published papers there is no explanation why this particular plant was chosen for the preparation of selenium nanoparticles. It can be inferred that the determining factor for such choice was the easy availability of the raw materials and some of these plants have traditional and pharmacological uses. Moreover, agricultural waste, such as fruit peels, could be used for synthesis. There is a maximum probability of succeeding by using plant materials which are rich in polyphenols, flavonoids, alkaloids, polysaccharides, saponins, etc. since they are very good reducing and stabilizing agents. Some literature works reported the content of phytochemicals present in prepared plant extracts such as total phenolic compounds and flavonoids [57, 77, 81], tannins [57] and polysaccharides [81] or phytochemical screening showing only qualitatively the presence of main active components $[58,61,72,76]$.

\section{Extraction}

Generally, the chosen part of the plant (leaves, buds, fruit, peel, nuts, seed or pulp) was washed thoroughly 
Table 1 Synthesis of SeNPs using different plants

\begin{tabular}{|c|c|c|c|}
\hline Plant & Extraction & Preparation of SeNPs & Refs. \\
\hline Hawthorn & $\begin{array}{l}10 \text { gof dried fruits }+200 \mathrm{~mL} \mathrm{H}_{2} \mathrm{O} \text {, refluxed for } \\
2 \mathrm{~h}\end{array}$ & $\begin{array}{l}\text { Extract }\left(2 \mathrm{mg} \mathrm{mL}^{-1}\right)+\mathrm{Na}_{2} \mathrm{SO}_{3}\left(10 \mathrm{~mol} \mathrm{~L}^{-1}\right) \\
\text { stirred for } 12 \mathrm{~h}\end{array}$ & 52 \\
\hline $\begin{array}{l}\text { Dried raisin } \\
\text { (Vitis vinifera) }\end{array}$ & Refluxed for 30 min with water & $\begin{array}{l}10 \mathrm{~mL} \text { extract }+90 \mathrm{~mL} \mathrm{H}_{2} \mathrm{SeO}_{3}\left(4 \times 10^{-5} \mathrm{~mol}\right. \\
\left.\mathrm{L}^{-1}\right) \text { refluxed for } 15 \mathrm{~min}\end{array}$ & 53 \\
\hline Lemon plant & $5 \mathrm{~g}+20 \mathrm{~mL}$ of Tris $-\mathrm{Cl}(\mathrm{pH} 7.5)$ & 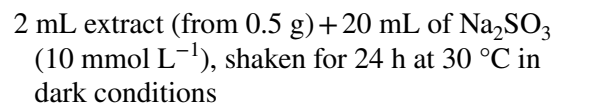 & 54 \\
\hline Bougainvillea spectabilis & $\begin{array}{l}100 \mathrm{~g} \text { of dried flowers }+100 \mathrm{~mL} \text { water, heated at } \\
70^{\circ} \mathrm{C} \text { for } 5-10 \mathrm{~min}\end{array}$ & $\begin{array}{l}10 \mathrm{~mL} \text { of extract }+90 \mathrm{~mL} 10 \mathrm{mmol} \mathrm{L}^{-1} \mathrm{Na}_{2} \mathrm{SeO}_{4} \\
\text { shaken at } 36^{\circ} \mathrm{C} \text { for } 5 \text { days }\end{array}$ & 55 \\
\hline Ginger fruit & - & $\begin{array}{l}1 \% \text { extract }+\mathrm{Na}_{2} \mathrm{SeO}_{3}\left(10 \mathrm{mmol} \mathrm{L}^{-1}\right) \text { at room } \\
\text { temperature stirred for } 75 \mathrm{~h}\end{array}$ & 56 \\
\hline Ashwagandha (Withania somnifera) & $\begin{array}{l}10 \mathrm{~g} \text { dried leaves }+500 \mathrm{~mL} \text { water, boiled for } \\
15 \mathrm{~min}\end{array}$ & $\begin{array}{l}0.1 \mathrm{~mL} \text { extract }+\mathrm{H}_{2} \mathrm{SeO}_{3}\left(50 \mathrm{mmol} \mathrm{L}^{-1}\right) \text { at room } \\
\text { temperature, centrifuged, washed with water } \\
\text { and acetone }\end{array}$ & 57 \\
\hline $\begin{array}{l}\text { Fenugreek } \\
\text { (Trigonella foenum-graecum) }\end{array}$ & $1 \%$ extract in water, stirring for $15 \mathrm{~min}$ & $\begin{array}{l}1 \mathrm{~mL} \text { of extract }+10 \mathrm{~mL} \mathrm{H}_{2} \mathrm{SeO}_{3}(30 \mathrm{mmol} \\
\left.\mathrm{L}^{-1}\right)+200 \mu \mathrm{L} \text { ascorbic acid }\left(0.04 \mathrm{~mol} \mathrm{~L}^{-1}\right) \\
\text { room temperature } 24 \mathrm{~h} \text {, washed with water, } \\
\text { then ethanol }\end{array}$ & 58 \\
\hline $\begin{array}{l}\text { Avaram } \\
\text { (Cassia auriculata) }\end{array}$ & $\begin{array}{l}5 \mathrm{~g} \text { of powdered leaves }+100 \mathrm{~mL} \text { water, soaked } \\
\text { for } 30 \mathrm{~min}\end{array}$ & $\begin{array}{l}\text { Extract }+100 \mathrm{~mL} \mathrm{Na}_{2} \mathrm{SeO}_{3}\left(10 \mathrm{mmol} \mathrm{L}^{-1}\right), \\
\text { incubated } 48 \mathrm{~h} \text { at room temperature }\end{array}$ & 59 \\
\hline $\begin{array}{l}\text { Arauna } \\
\text { (Terminalia arjuna) }\end{array}$ & $5 \mathrm{~g}+20 \mathrm{~mL}$ of $\mathrm{TrisCl}(\mathrm{pH} 7.5)$ & $\begin{array}{l}2 \mathrm{~mL} \text { of extract }+20 \mathrm{~mL} \text { of } \mathrm{Na}_{2} \mathrm{SeO}_{3}(10 \mathrm{mmol} \\
\left.\mathrm{L}^{-1}\right) \text {, shaken at } 30{ }^{0} \mathrm{C} \text { for } 72 \mathrm{~h} \text { in dark condi- } \\
\text { tions, washed with ethanol }\end{array}$ & 60 \\
\hline Java tea & $\begin{array}{l}50 \mathrm{~g} \text { of dried leaves }+300 \mathrm{~mL} \text { water, stirring for } \\
15 \mathrm{~min} \text {, kept for } 24 \mathrm{~h}\end{array}$ & $\begin{array}{l}1 \mathrm{~mL} \text { of extract }+10 \mathrm{~mL} \text { of } \mathrm{H}_{2} \mathrm{SeO}_{3}(10 \mathrm{mmol} \\
\left.\mathrm{L}^{-1}\right)+200 \mu \mathrm{L} \text { ascorbic acid }\left(40 \mathrm{mmol} \mathrm{L}^{-1}\right) \\
24 \mathrm{~h} \text { at room temp. washed with water and } \\
\text { absolute alcohol }\end{array}$ & 61 \\
\hline $\begin{array}{l}\text { Lavender leucas } \\
\text { (Leucs lavandulifolia) }\end{array}$ & $\begin{array}{l}10 \mathrm{~g} \text { of dry plant }+400 \mathrm{~mL} \text { water, boiled for } \\
5 \mathrm{~min}\end{array}$ & $\begin{array}{l}2 \mathrm{~mL} \text { of extract }+10 \mathrm{~mL}^{-1} \mathrm{H}_{2} \mathrm{SeO}_{3}(50 \mathrm{mmol} \\
\left.\mathrm{L}^{-1}\right)+200 \mu \mathrm{L} \text { of ascorbic acid }\left(40 \mathrm{mmol} \mathrm{L}^{-1}\right)\end{array}$ & 62 \\
\hline Aloe vera & $30 \mathrm{~g}$ of fresh leaves $+20 \mathrm{~mL}$ water & $\begin{array}{l}\left.25 \mathrm{~mL}_{\text {of } \mathrm{Na}_{2} \mathrm{SeO}_{3}(5 \mathrm{mmol} \mathrm{L}}^{-1}\right)+ \text { plant extract } \\
\text { until color was changed, later kept for } 72 \mathrm{~h}\end{array}$ & 63 \\
\hline Aloe vera & $\begin{array}{l}4.69 \mathrm{~g} \text { of dried leaves }+100 \mathrm{~mL} \text { of boiling water, } \\
5 \mathrm{~min}\end{array}$ & 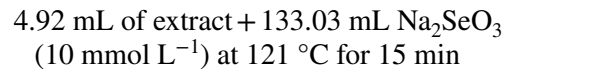 & 64 \\
\hline $\begin{array}{l}\text { Garlic } \\
\text { (Allium sativum) }\end{array}$ & $10 \mathrm{~g}$ of garlic buds + water to make a thin paste & $\begin{array}{l}25 \mathrm{~mL} \text { of } \mathrm{Na}_{2} \mathrm{SeO}_{3}(5 \mathrm{mmol} \mathrm{L} \\
\text { color was changed, kept for } 72 \mathrm{~h} \text {. in dark }\end{array}$ & 65 \\
\hline $\begin{array}{l}\text { Garlic } \\
\text { (Allium sativum) }\end{array}$ & Garlic buds + water to make a thin paste & $\begin{array}{l}2 \mathrm{~mL} \text { of extract }(2 \%)+8 \mathrm{~mL} \text { of } \mathrm{H}_{2} \mathrm{SeO}_{3} \\
\left(30 \mathrm{mmol} \mathrm{L}^{-1}\right)+200 \mu \mathrm{L} \text { of ascorbic acid } \\
\left(40 \mathrm{mmol} \mathrm{L}^{-1}\right), 48 \mathrm{~h} \text { for incubation }\end{array}$ & 66 \\
\hline $\begin{array}{l}\text { Garlic } \\
\text { (Allium sativum) }\end{array}$ & $10 \mathrm{~g}$ of garlic buds + water to make a thin paste & $\begin{array}{l}\text { Extract was added dropwise to } 25 \mathrm{~mL} \mathrm{Na}_{2} \mathrm{SeO}_{3} \\
\left(5 \mathrm{mmol} \mathrm{L}^{-1}\right), \text { kept } 72 \mathrm{~h} \text { in dark }\end{array}$ & 67 \\
\hline $\begin{array}{l}\text { Garlic } \\
\text { (Allium sativum) }\end{array}$ & $\begin{array}{l}5 \mathrm{~g} \text { of crushed gloves macerated with } 30 \mathrm{~mL} \text { of } \\
\text { Tris- } \mathrm{Cl}(\mathrm{pH} 7.5)\end{array}$ & $\begin{array}{l}20 \mathrm{~mL} \text { of extract }+ \text { dropwise } 20 \mathrm{~mL} \text { of } \mathrm{Na}_{2} \mathrm{SeO}_{3} \\
(10 \mathrm{mmol} \mathrm{L}-1), 5-7 \text { days at } 36^{\circ} \mathrm{C}\end{array}$ & 68 \\
\hline $\begin{array}{l}\text { Garlic } \\
\text { (Allium sativum) }\end{array}$ & - & $\begin{array}{l}0.06 \mathrm{~g} \text { of garlic extract }+20 \mathrm{~mL} \text { of } \mathrm{Na}_{2} \mathrm{SeO}_{3} \\
\left(10 \mathrm{mmol} \mathrm{L}^{-1}\right) \text {, incubated } 4,24,48 \text { and } 72 \mathrm{~h}\end{array}$ & 69 \\
\hline $\begin{array}{l}\text { Walnut } \\
\text { (Juglans regia) }\end{array}$ & $\begin{array}{l}1 \mathrm{~g} \text { of leave powder }+100 \mathrm{~mL} \text { water, boiling for } \\
5 \mathrm{~min}\end{array}$ & $\begin{array}{l}5 \mathrm{~mL} \text { of extract }+\mathrm{Na}_{2} \mathrm{SeO}_{3}\left(10 \mathrm{mmol} \mathrm{L}^{-1}\right) \\
\text { heated using microwave oven }(800 \mathrm{~W} \text { for } \\
4 \mathrm{~min})\end{array}$ & 70 \\
\hline $\begin{array}{l}\text { Horseshoe geranium } \\
\text { (Pelargonium zonale) }\end{array}$ & $\begin{array}{l}2 \mathrm{~g} \text { of powdered leaves }+100 \mathrm{~mL} \text { of boiling } \\
\text { water, mixed for } 5 \mathrm{~min}\end{array}$ & $\begin{array}{l}1.48 \mathrm{~mL} \text { of extract }+15 \mathrm{~mL} \text { of } \mathrm{Na}_{2} \mathrm{SeO}_{3} \\
(10 \mathrm{mmol} \mathrm{L}-1) \\
\text { heated using microwave oven ( } 800 \mathrm{~W} \text { for } 4 \mathrm{~min})\end{array}$ & 71 \\
\hline Asteriscus graveolens & $\begin{array}{l}2 \mathrm{~g} \text { of powdered aerial part }+200 \mathrm{~mL} \text { water, } \\
\text { boiled for } 1 \mathrm{~h}\end{array}$ & $\begin{array}{l}75 \mathrm{~mL} \text { of extract }+25 \mathrm{~mL} \text { of } \mathrm{Na}_{2} \mathrm{SeO}_{3}(10 \mathrm{mmol} \\
\left.\mathrm{L}^{-1}\right) \text {, incubated in dark for } 24 \mathrm{~h}\end{array}$ & 72 \\
\hline Catharanthus roseus & $\begin{array}{l}10 \mathrm{~g} \text { of flowers }+100 \mathrm{~mL} \text { water, heated at } 90^{\circ} \mathrm{C} \\
\text { for } 5 \mathrm{~min}\end{array}$ & $\begin{array}{l}10 \mathrm{~mL} \text { of extract }+90 \mathrm{~mL} \text { of } \mathrm{Na}_{2} \mathrm{SeO}_{3}(10 \mathrm{mmol} \\
\left.\mathrm{L}^{-1}\right) \text {, kept at } 36^{\circ} \mathrm{C} \text { for a week }\end{array}$ & 73 \\
\hline Orange peel & $\begin{array}{l}50 \mathrm{~g} \text { of grounded peels }+150 \mathrm{~mL} \text { water, boiled } \\
\text { for } 15 \mathrm{~min}\end{array}$ & $\begin{array}{l}50 \mathrm{~mL} \text { of extract }+5 \mathrm{~mL} \text { of } \mathrm{Na}_{2} \mathrm{SeO}_{3}(100 \mathrm{mmol} \\
\left.\mathrm{L}^{-1}\right)\end{array}$ & 74 \\
\hline
\end{tabular}


Table 1 (continued)

\begin{tabular}{|c|c|c|c|}
\hline Plant & Extraction & Preparation of SeNPs & Refs. \\
\hline Clausena dentata & $\begin{array}{l}10 \mathrm{~g} \text { of powdered leaves }+100 \mathrm{~mL} \text { water, boiled } \\
\text { at } 60^{\circ} \mathrm{C} \text { for } 5 \mathrm{~min}\end{array}$ & $\begin{array}{l}12 \mathrm{~mL} \text { of extract }+88 \mathrm{~mL} \text { of selenium powder } \\
\left(1 \mathrm{mmol} \mathrm{L}^{-1}\right)\end{array}$ & 75 \\
\hline $\begin{array}{l}\text { Mountain persimmon } \\
\text { (Diospyros Montana) }\end{array}$ & - & 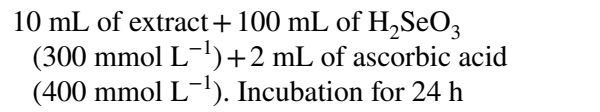 & 76 \\
\hline Emblica officinalis & $100 \mathrm{~g}$ of edible grounded fruit + water $(1: 2, \mathrm{w} / \mathrm{v})$ & $\begin{array}{l}2 \mathrm{~mL} \text { of extract }+10 \mathrm{~mL} \text { of } \mathrm{Na}_{2} \mathrm{SeO}_{3}(100 \mathrm{mmol} \\
\left.\mathrm{L}^{-1}\right), \text { in dark for } 24 \mathrm{~h}\end{array}$ & 77 \\
\hline Ficus benghalensis & $\begin{array}{l}25 \mathrm{~g} \text { of dry leaves }+100 \mathrm{~mL} \text { of water, boiled at } \\
100{ }^{\circ} \mathrm{C}\end{array}$ & $\begin{array}{l}\text { Se powder }\left(0.6 \mathrm{~mol} \mathrm{~L}^{-1}\right)+\mathrm{Na}_{2} \mathrm{~S}(3.87 \mathrm{~mol} \\
\left.\mathrm{L}^{-1}\right) \text { dissolved in } 10 \mathrm{~mL} \text { of water, refluxed at } \\
90{ }^{\circ} \mathrm{C} \text { for } 1 \mathrm{~h} \text {. Then the formed } \mathrm{SeS}_{2}(0.5 \mathrm{~mol} \\
\left.\mathrm{L}^{-1}\right)+100 \mathrm{~mL} \text { of water }+5 \mathrm{~mL} \text { of extract, } \\
\text { stirred for } 10 \mathrm{~min} \text { at room temperature }\end{array}$ & 78 \\
\hline Drumstick (Moringa oleifera) & $\begin{array}{l}\text { Leaves soaked in } 100 \mathrm{~mL} \text { of water at } 67^{\circ} \mathrm{C} \text { for } \\
4 \mathrm{~h}\end{array}$ & $\begin{array}{l}\text { Selenium salt }(1 \mathrm{~g} / 100 \mathrm{~mL})+\text { extract, kept for } \\
24 \mathrm{~h} \text { at room temperature }\end{array}$ & 79 \\
\hline Guava (Psidium guajava) & $\begin{array}{l}10 \mathrm{~g} \text { of leaves }+100 \mathrm{~mL} 60 \% \text { ethanol, boiled for } \\
2 \mathrm{~min}\end{array}$ & $\begin{array}{l}100 \mathrm{~mL} \text { of extract }+900 \mathrm{~mL} \text { of } \mathrm{Na}_{2} \mathrm{SeO}_{3} \\
\left(25 \mathrm{mmol} \mathrm{L}^{-1}\right) \text {, at } 60^{\circ} \text {, incubating for } 3 \mathrm{~h}\end{array}$ & 80 \\
\hline $\begin{array}{l}\text { Cacao bean shell } \\
\text { (Theobroma cacao L.) }\end{array}$ & $\begin{array}{l}6 \mathrm{~g} \text { of grounded material + water, adjusted to } \mathrm{pH} \\
2 \text {, heated in the microwave oven }(500 \mathrm{~W}) \text { at } \\
100{ }^{\circ} \mathrm{C} \text { for } 5 \mathrm{~min}\end{array}$ & $\begin{array}{l}50 \mathrm{~mL} \text { of extract }+0.14 \mathrm{~g} \text { of } \mathrm{Na}_{2} \mathrm{SeO}_{3} \text {, heating in } \\
\text { the microwave oven }(788.6 \mathrm{~W}) \text { for } 15.6 \mathrm{~min}\end{array}$ & 81 \\
\hline
\end{tabular}

Fig. 1 Scheme for the synthesis of selenium nanoparticles using plant extract

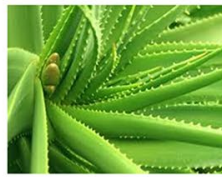

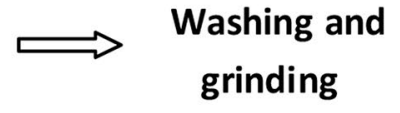

Plant`s part

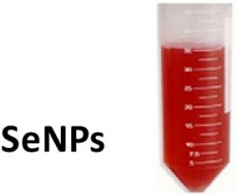

\section{Synthesis}

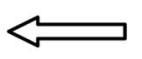

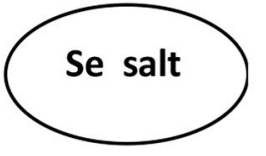

\section{Soaking or boiling in water}

$\int$ Filtration 
stability [82]. Many factors affect the obtained nanoparticles, including temperature, $\mathrm{pH}$, extract concentration, type, and concentration of the used precursor. In some papers response surface methodology (RSM) was applied to develop the empirical models for the prediction of the optimal synthesis conditions [64, 71, 81].

In a typical experiment, selenium precursor (sodium selenite or selenate, selenous acid, sodium selenosulphate) was mixed with the plant extract solution at different ratio. The addition of ascorbic acid was used in some procedures as an initiator of reduction reaction $[58,61,62,66,76]$. The reacting solution was stirred at room temperature in different time intervals; from $12 \mathrm{~h} \mathrm{[52]}$ to $72 \mathrm{~h}[53,57,60,62$, $64]$ and even for 5-7 days [68,73], sometimes in the dark. Another group of proposed procedures includes heating the mixture at the desired temperature and time. During that incubation process, the colour of the reaction media changes to red, indicating the formation of Se nanoparticles. Finally, the SeNPs can be separated by centrifuging at high speed, washed thoroughly in water and solvent.

The proposed methods for selenium nanoparticles using plant extracts show similarity in the synthesis procedure with little modifications (Table 1). Deepa and Ganesa [73] used $\mathrm{Na}_{2} \mathrm{SeO}_{4}$ as the selenium precursor for reduction reaction, while most often Se(IV) species are applied. This fact was explained by the authors by a long incubation time of 1 week for SeNPs preparation using extract from the flower of Catharanthus roseus. Santanu et al. [74] reported that the time required for conversion of selenium selenite to SeNPs was indirectly related to the reduction ability of orange peel extract. The extraction process was found to be the most effective when conducted for $15 \mathrm{~min}$ at $40{ }^{\circ} \mathrm{C}$ and $\mathrm{pH} 4$.

Melinas et al. [81] proposed the extract from Theobroma cacao L. bean shell as a reductant and capping agent for SeNPs synthesis. The kinetic of reaction was increased due to the use of microwave irradiation with rapid initial heating. It was concluded that SeNPs crystalline size was not significantly affected by time and microwave power and only low amounts of the Se precursor were needed to obtain smallsized nanoparticles. The optimized through RSM synthesis parameters were: $15.6 \mathrm{~min}, 788.6 \mathrm{~W}, 0.14 \mathrm{~g}$ of sodium selenite and $50 \mathrm{~mL}$ of extract solution.

Fardsadegh et al. [71] also used RSM methodology to obtain the optimal condition for fabrication of selenium nanoparticles using Pelargonium zonale leaf extract. They evaluated the effects of selenium precursor amount and plant extract on the $\lambda_{\max }$ value, as higher $\lambda_{\max }$ correlated to larger particle size. The increase in the amount of $\mathrm{Na}_{2} \mathrm{SeO}_{3}$ at a constant amount of the plant extract, generated the increase of $\lambda_{\max }$ (Fig. 2). Similar trend was observed for increasing amount of extract at constant amount of $\mathrm{Na}_{2} \mathrm{SeO}_{3}$ solution.

The synthesis with Aloe vera leaf extract was conducted under subcritical water conditions due to its capability to generate simultaneously high pressure and high temperature [64]. This hydrothermal synthesis was completed within 15 min. Additionally, central composite design with RSM models were used to evaluate the effects of synthesis parameters on the colour intensity and particle size (Fig. 3). It was found that at a constant amount of $\mathrm{Na}_{2} \mathrm{SeO}_{3}$, the increase in the amount of extract also caused the increase in SeNPs concentration, observed as the increase in colour intensity. On the other side, at a constant amount of Aloe vera extract, the colour intensity decreased with the increase of the amount of $\mathrm{Na}_{2} \mathrm{SeO}_{3}$ solution. Such result was explained by the fact that in the small amounts of plant extract, reducing agents react with selenium ions completely. In fact, the increase in $\mathrm{Na}_{2} \mathrm{SeO}_{3}$ solution amount was causing the increase in the amount of Se ions, while the number of synthesized SeNPs was constant. Their concentration decreased due to an increase in the volume of the reaction solution.
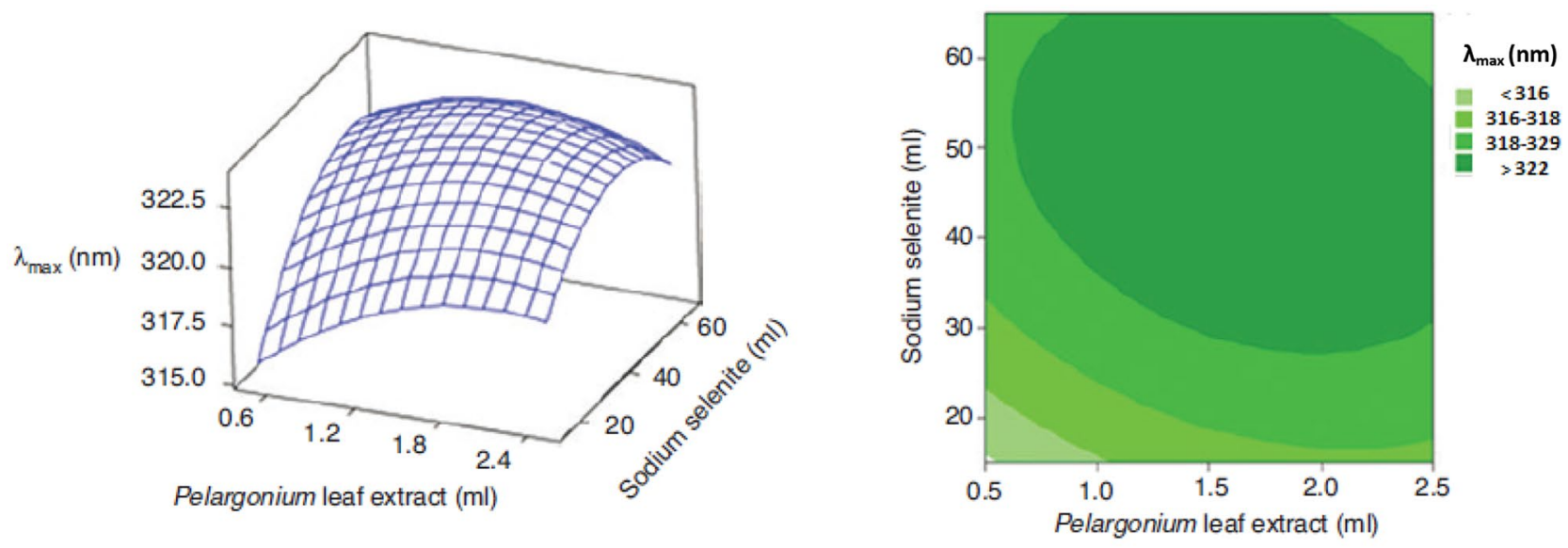

Fig. 2 Surface and contour plots for $\lambda_{\max }$ of the synthesized SeNPs as a function of amounts of $\mathrm{Na}_{2} \mathrm{SeO}_{3}$ solution and Pelargonium zonale leaf extract. Reprinted with permission by De Gruyter GmbH from Ref. [71] 

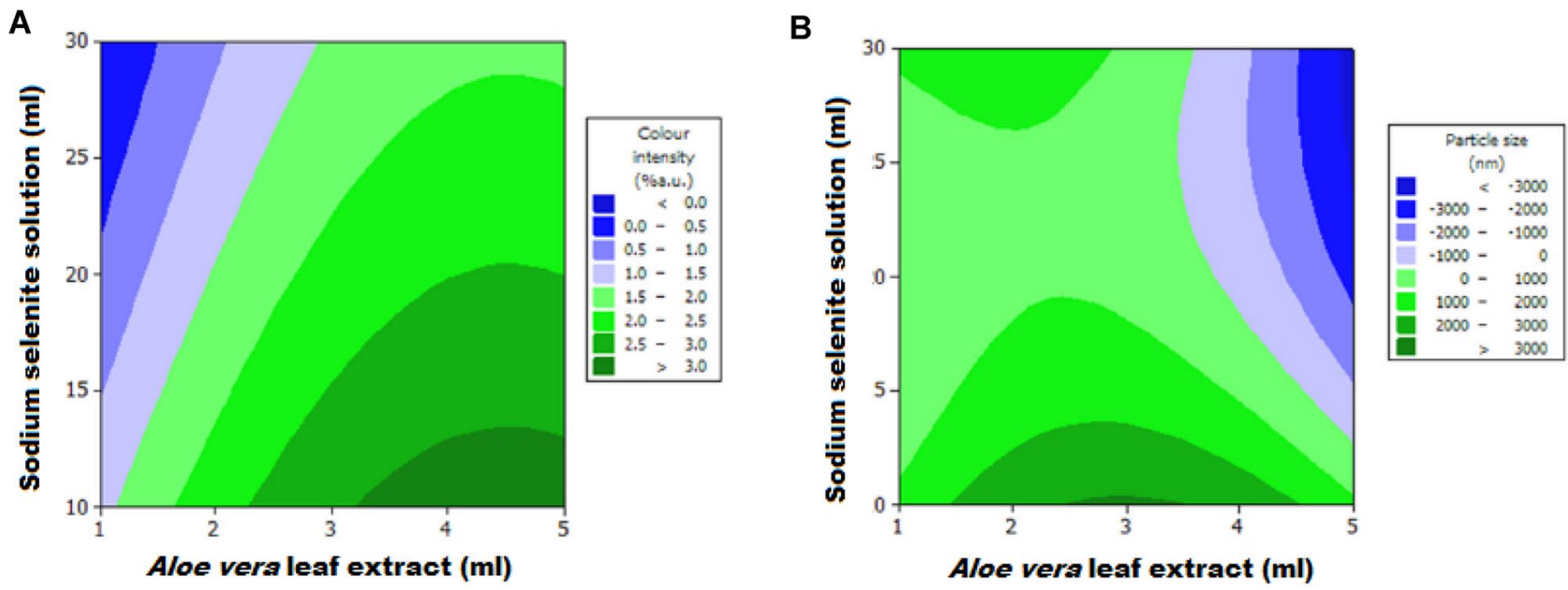

Fig. 3 Contour plots of (A) color intensity and (B) particle size of the solution containing SeNPs as a function of the amount of $\mathrm{Na}_{2} \mathrm{SeO}_{3}$ solution and Aloe vera leaf extract. Reprinted with permission by De Gruyter GmbH from Ref. [64]

\section{Characterization of SeNPs}

The prepared SeNPS were characterized by various spectroscopic and microscopic methods to evaluate their elemental composition, exact morphology and also other physicochemical properties. UV-Vis absorption spectra were recorded for the indication of the Se nanoparticles formation. The color change of the reaction mixture from uncoloured to reddish confirms the synthesis of SeNPs. It was further validated by the progressive rise in optical phenomenon within the characteristic peak between 200 and $400 \mathrm{~nm}$ with the increase in reaction time. In the absorption spectra of SeNPs the redshift occurs because the particle sizes increase $[52,53,66$, 68]. It is worth mentioning that SeNPs synthesized using the reducing potential of various bacteria gave a characteristic peak at $450-600 \mathrm{~nm}$. It had be explained by the diversity of enzymes which catalyze the reduction reaction [43]. Atomic absorption spectroscopy was also used to study the conversion of selenium ions at various time intervals by determining its remaining concentration in supernatant [50].

Scanning emission microscopy (SEM) and transmission electron microscopy (TEM) measurements revealed their size, shape, agglomeration and distribution. Dynamic light scattering (DLS) also helps in the measurement of the particle size and distribution. In some cases, the disagreement between the sizes obtained by TEM and DLS was observed due to the fact that TEM analyzes the metallic core while DLS measures the hydrodynamic volume.

Energy dispersive spectroscopy (EDS) was used for the examination of elemental composition and purity of nanoparticles. The highest content of selenium (82\%) in nanoparticles was obtained using the leaf extract of Cassia auriculata [59], followed by Clausena dentate (72.6\%) [75] and Emblica officinalis (61.6\%) [77]. EDS analysis of SeNPs revealed the proportion of Se equals to $55 \%$ when the extract of garlic bulbs was utilized [63, 65]. Similar values of 54\% were reported for ginger fruit [56] and herb Withania sonnitfera extracts [57]. The other peaks being observed in EDS spectrum were carbon, oxygen, nitrogen, and sodium.

Fourier transform infrared (FTIR) spectroscopy was used to confirm the involvement of $\mathrm{O}-\mathrm{H}, \mathrm{N}-\mathrm{H}, \mathrm{C}=\mathrm{O}$ and $\mathrm{C}-\mathrm{O}$ functional groups during the formation of SeNPs, which were associated with bioactive molecules capping their surface [53-58, 62-68, 71, 75-77]. The peaks at $1375 \mathrm{~cm}^{-1}$, $1030 \mathrm{~cm}^{-1}, 1462 \mathrm{~cm}^{-1}$ and $1250 \mathrm{~cm}^{-1}$ representing phenolic $\mathrm{OH}$, aromatic in-plane $\mathrm{C}-\mathrm{H}$ bending, asymmetric $\mathrm{C}-\mathrm{H}$ bending (in $\mathrm{CH}_{3}$ and $-\mathrm{CH}_{2}-$ ) and secondary $\mathrm{OH}$, respectively can be found after the green synthesis of SeNPs. The peaks at 2840 and $2930 \mathrm{~cm}^{-1}$ representing ether-methoxy- $\mathrm{OCH}_{3}$ groups, show the presence of the biopolymer lignin associated with SeNPs [53]. Also, novel composite containing TEMPO cellulose, chitosan, starch and selenium nanoparticles was synthesized confirming its structure by FTIR [78]. $\mathrm{X}$-ray diffraction (XRD) pattern reflects the morphology of selenium nanoparticles and their crystalline nature. [42, 48, 53, 60, 73, 75-77]. Raman spectroscopy analysis provides the unique feature of vibrational characteristics of crystal or amorphous nature of SeNPs [66, 77, 84].

The stability of selenium nanoparticles was evaluated by measuring the zeta potential. SeNPs synthesised by plant extracts are covered by a bioorganic layer comprising proteins, polysaccharides and lipids, with a significant proportion of ionised carboxylic groups. These groups, which are typical both of side-chains of some amino acid residues and carboxylated polysaccharides, are responsible for the negative values of SeNPs zeta potentials. The obtained magnitudes deliver information on particle stability. When this absolute value is higher than $30 \mathrm{mV}$, the colloidal solution 
can be considered stable, and there is no agglomeration or flocculation [85]. From literature, it may be observed that the lowest values of zeta potential equals to $-36 \mathrm{~V}$ were reported for SeNPs synthesized using the extract from lemon plant [53] and ginger fruit [54], followed by the extract of Java tea $(-34.9 \mathrm{~V})$ [59] and cacao bean shell (-28.6 V) [81]. The synthesized SeNPs with the spherical average of $24.3 \mathrm{~nm}$ found to be stable for more than three months without forming any aggregates [54]. Mellinas et al. [82] observed a significant interaction between the reaction time and the amount of $\mathrm{Na}_{2} \mathrm{SeO}_{3}$ (used for the preparation of the precursor solution) on Z-potential. As shown in Fig. 4, the Z-potential as a function of these variables has a minimum. Initially, the $Z$-potential value decreased with increasing reaction time and the concentration of precursor. After reaching the minimum, the Z-potential increased with increasing both reaction time and the amount of sodium selenite. This was explained by the increase of the free energy of the system that favours the aggregation of nanoparticles and then the decrease in their stability. When the time of synthesis was increased and the amount of Se precursor decreased, SeNPs showed higher stability, which was largely attributed to the stabilizing effect of compounds present in the plant extract.

The incubation temperature during the synthesis of SeNPs could affects their size, shape, and bioavailability. Zhang et al. [86] reported that the $80 \mathrm{~nm}$ SeNPs after incubation at $90{ }^{\circ} \mathrm{C}$ for $1 \mathrm{~h}$ resulted in aggregated into larger $110 \mathrm{~nm}$ particles and nanorods $(290 \mathrm{~nm} \times 70 \mathrm{~nm})$.

\section{Antioxidant properties of SeNPs}

The functions of selenium in the organism are mainly connected with its antioxidant properties, as it is an essential component of antioxidant enzymes such as the glutathione peroxidise group and thioredoxin reductase. They have important roles in scavenging free radicals such as reactive oxygen and nitrogen species, regulating their content produced during the biochemical reaction, Thus, they protect cells from damage and oxidative stress. SeNPs can increase selenoenzyme activities with equal efficiency but less toxicity, compare to other selenium species $[9,87]$.

The antioxidant activity of different Se species is still studied [87, 88], but the newest research has also involved selenium nanoparticles [56, 57, 63, 67, 76, 82, 83, 90, 91]. The evaluation of the antioxidant potential of SeNPs was performed using various assays, including 2,2'-diphenylhydrazyl (DPPH) and 2,2'-azino-bis(3-ethylbenzothiazoline-6-sulphonic acid) (ABTS) as well as ferric reducing antioxidant power (FRAP) using standard procedures [92]. However, these methods vary in terms of antioxidant mechanism, redox potential, type of substrate, chemical conditions as well as the way of presenting the results. There is a strong recommendation to use at least two assays which measure different aspects of the antioxidant behavior due to the lack of a standard method for this purpose [93].

Menon et al. [56] compared the percentage of inhibition ratio of SeNPs synthesized using extract of ginger with that of ascorbic acid as a standard compound in a dosedependent manner in DPPH assay. It showed moderate antioxidant activity as the $\mathrm{IC}_{50}$ value of SeNPs was estimated at $125 \mu \mathrm{g} \mathrm{mL}^{-1}$, while for ascorbic acid was $250 \mu \mathrm{g} \mathrm{mL}^{-1}$. As $\mathrm{IC}_{50}$ value for SeNPs was lower than that for ascorbic acid, so a higher concentration of this compound is needed to produce a similar effect. Alagesan and Venugopal [57] reported the $\mathrm{IC}_{50}$ value of $14.81 \mu \mathrm{g} \mathrm{mg}{ }^{-1}$ for similar studies using leaves extract of Withania somnifera for preparation of SeNPs within the diameter range of $45-90 \mathrm{~nm}$.

Completely opposite results were obtained for Diospyros montana leaf extract-mediated synthesis of selenium nanoparticles $(4-16 \mathrm{~nm})$ which exhibited $61 \%$ of scavenging activity in DPPH method at the concentration of $200 \mu \mathrm{g} \mathrm{mL}^{-1}$, compared to the same concentration of ascorbic acid (almost 100\%) [76]. The $\mathrm{IC}_{50}$ value of the nanoparticles was $0.225 \mu \mathrm{g} \mathrm{mL}^{-1}$, while $0.138 \mu \mathrm{g} \mathrm{mL}^{-1}$ for ascorbic acid. Also in FRAP method, the synthesized SeNPs exhibited better reducing power than that of standard ascorbic acid as the $\mathrm{EC}_{50}$ values of $0.435 \mu \mathrm{g} \mathrm{mL}^{-1}$ and $0.083 \mu \mathrm{g} \mathrm{mL}^{-1}$ were reported [76]. The size of the SeNPs may affect their
Fig. 4 Response surface plot showing synthesis time $v s$. $\mathrm{Na}_{2} \mathrm{SeO}_{3}$ amount on Z-potential of SeNPs using Theobroma cacao bean shell extract. The Z-potential values on the vertical axis are presented as absolute values. Reprinted with permission by MDPI from Ref. [81]

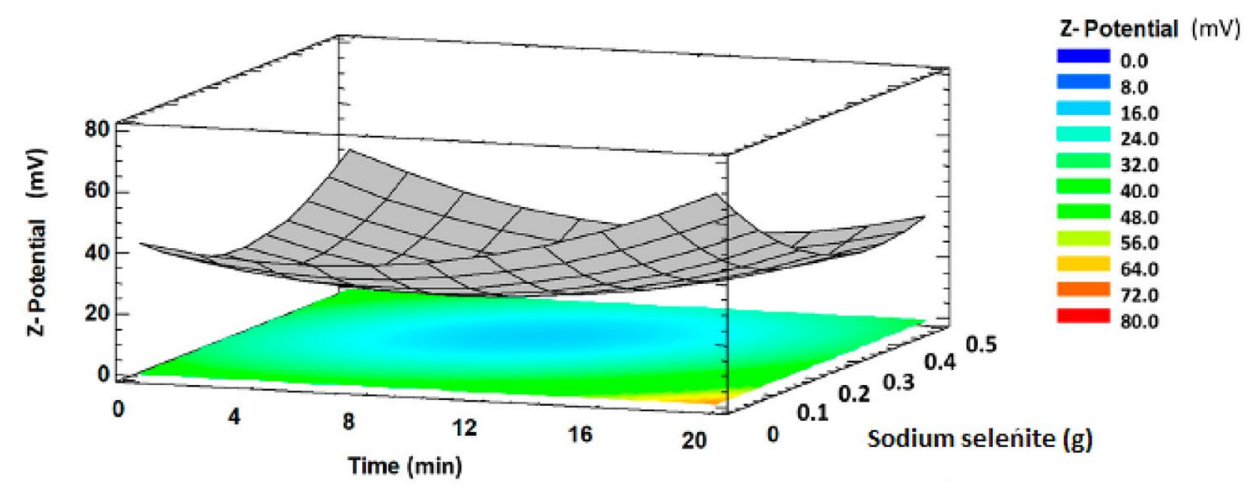


antioxidant property and the nanoparticles with smaller diameters showed the stronger antioxidant activity $[81,93]$.

Vyas and Rana found that the average inhibition percentage in DPPH and ABTS assays were $75 \%$ and $76 \%$, respectively, in comparison to single Aloe vera [63] and Allium sativum [67] extracts for SeNPs synthesized using these plant extracts. The obtained results were also higher than those determined for rutin as a standard compound (Fig. 5). However, in FRAP assay rutin showed more reducing activity than both biosynthesized selenium nanoparticles.

The values in ABTS and FRAP assays of 28.6 and $12.4 \mathrm{mg}$ of Trolox equivalent per gram of nanoparticles,

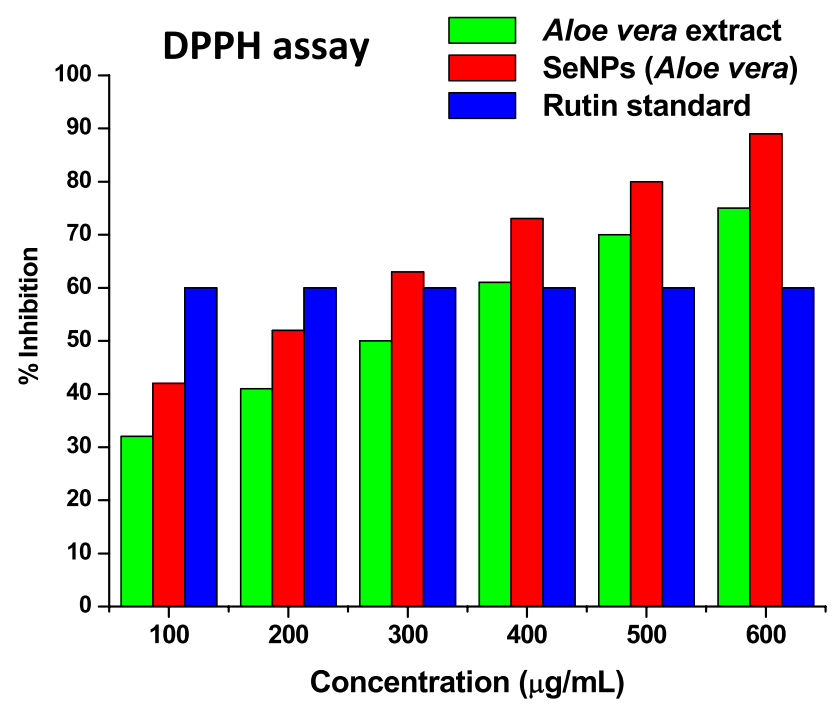

FRAP assay

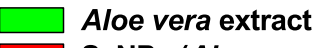
SeNPs (Aloe vera) Rutin standard

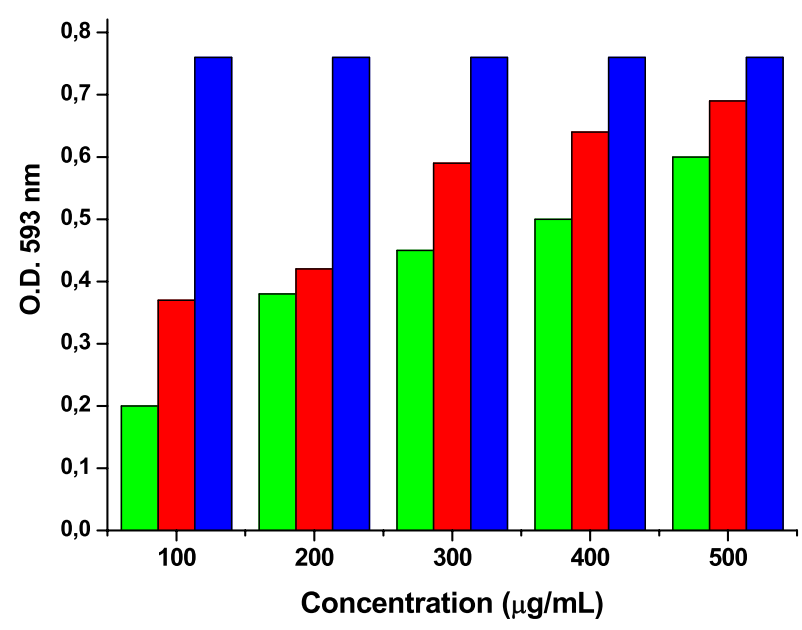

Fig. 5 Antioxidant properties of SeNPs synthesized by Aloe vera extract evaluated using DPPH and FRAP assays. Reprinted with permission by Innovare Academic Sciences Pvt. Ltd. from Ref. [63] respectively, were reported for SeNPs synthesized with Theobroma cacao L. bean shell extract [82]. No significant differences $(p=0.05)$ were observed between samples analysed at different time up to 55 days. These nanoparticles possess higher antioxidant activity than the used plant extract itself, such as for SeNPs synthesized with other natural extracts $[63,67,94]$.

\section{Application of SeNPs}

Biosynthesized SeNPs have been used in different areas such as medical, agriculture, and industrial sectors because they exhibit low toxicity and are environmentally friendly (Table 2). In this section of review, the main applications of selenium nanoparticles synthesized using the extracts of plant materials are briefly described. More details can be found in several recent review papers [6-10, 95-99].

Several reports have confirmed the anticancer effect of SeNPs obtained by green synthesis $[52,54,57-59,66,72$, $76,77]$. Various mechanisms have been suggested for Se anticancer activity including cell cycle arrest, antioxidation, apoptosis, and interruption of cell signalling pathway and there is a lot of literature available on this topic [7, 9, 90, 100-104]. SeNPs can act as a carrier for chemotherapeutic drugs delivering them to the target side, selectively accumulated inside the malignant cells, and caused the reactive oxygen species formation. The production of these reactive species was more efficient than by Se(IV) in a mouse model, generating potent therapeutic effects and promising strategy for cancer therapy [87]. Cui et al. [52] reported that selenium nanoparticles synthesized with hawthorn fruit extract induced HepG2 cells apoptosis mediated through the mitochondria pathway with the promotion of reactive oxygen species. MTT assay revealed higher growth control against A549 lung carcinoma [57] and MCF 7 human breast [58] cancer cells as well as showed good viability against L6 rat skeletal muscle cell line [61] on treatment with SeNPs with minimal toxicity. Additionally, the combination of SeNPs with doxorubicin (chemotherapy drug used to treat cancer) enhanced the cytotoxic effect in comparison to individual ones [53].

Casia auriculata leaf extract generated SeNPs exhibited cytotoxicity against Vero cells with the cytotoxic concentration required for the reduction of cell viability by $50 \%$ $\left(\mathrm{CC}_{50}\right)$ of $7.00 \mu \mathrm{g} \mathrm{mL}^{-1}$ [59] and for those synthesized using garlic gloves $\mathrm{CC}_{50}$ value was higher $\left(31.8 \mu \mathrm{g} \mathrm{mL}^{-1}\right)$, while Vero cells treated with chemically synthesized nanoparticles (in the presence of polyvinylalcohol as a stabilizer) led to $\mathrm{CC}_{50}$ of $18.8 \mu \mathrm{g} \mathrm{mL}^{-1}$ [68]. This proves that cytotoxicity of SeNPs differs depending on the technology used to synthesis of nanomaterial. Biosynthesized SeNPs exhibited also 
Table 2 Morphology, particle size, Se content and potential applications of SeNPs synthesized using corresponding plant extract

\begin{tabular}{|c|c|c|c|c|c|}
\hline Plant & Morphology & $\begin{array}{l}\text { Size by SEM/ } \\
\text { TEM studies } \\
(\mathrm{nm})\end{array}$ & Se content $(\%)$ & Medical effect/application & Refs. \\
\hline Hawthorn & spherical & average 113 & 25.6 & $\begin{array}{l}\text { Antitumor activity towards HepG2 cells } \\
\text { Chemotherapic agent for human liver cancer }\end{array}$ & 52 \\
\hline Dried raisin & nanoballs & $3-18$ & - & Potential pharmaceutical & 53 \\
\hline Lemon plant & spherical & $60-80$ & 48 & $\begin{array}{l}\text { Prevention of DNA damage when cells were exposed to } \\
\text { UVB. Diagnostic agent }\end{array}$ & 54 \\
\hline Bugenwilla & hollow and spherical & $18-35$ & - & - & 55 \\
\hline Ginger fruit & spherical & $100-150$ & 54 & Antimicrobal activity against Proteus sp. & 56 \\
\hline Ashwagandha & spherical & $40-90$ & - & $\begin{array}{l}\text { Antibacterial activity against Klebsiella pneumomiae } \\
\text { and Bacillus subtillis. High control against A549 lung } \\
\text { carcinoma cancer cells. Efficiency of degrading meth- } \\
\text { ylene blue dye under sunlight irradiation }\end{array}$ & 57 \\
\hline Fenugreek & oval & $50-150$ & - & Inhibiting the breast-cancer cells (MCF-7) growth & 58 \\
\hline Avaram & spherical & $10-20$ & 82 & Antileukemia activity & 59 \\
\hline Arauna & spherical & $10-80$ & - & $\begin{array}{l}\text { Minimizing arsenic-induced toxicity on human lympho- } \\
\text { cytes }\end{array}$ & 60 \\
\hline Java tea & spherical & $88-141$ & 12.6 & Cytotoxic effect against L6 cell lines & 61 \\
\hline Lavender leucas & spherical & $56-75$ & - & Antibacterial and anti-fungal activity & 62 \\
\hline Aloe vera & spherical & $7-48$ & 25 & Chemopreventive agent in cancer diagnosis & 63 \\
\hline Aloe vera & spherical & 121 & - & $\begin{array}{l}\text { Antimicrobial activity against spoilage fungi and patho- } \\
\text { genic bacteria strain }\end{array}$ & 64 \\
\hline Garlic & hollow and spherical & $8-52$ & 55 & Antimicrobial activity against gram-positive bacteria & 65 \\
\hline Garlic & spherical & $10-80$ & - & Direct interaction with DNA. Anticancer agent & 66 \\
\hline Garlic & spherical & $7-45$ & 55 & Potential antioxidant agent & 67 \\
\hline Garlic & spherical & $40-100$ & - & Cytotoxicity against Vero cells & 68 \\
\hline Garlic & spherical & $21-40$ & - & Antibacterial agent against Staphylococcus aureus & 69 \\
\hline Walnut & spherical & 150 & - & $\begin{array}{l}\text { Antibacterial activity against Escherichia coli and } \\
\text { Staphylococcus aureus }\end{array}$ & 70 \\
\hline Horseshoe geranium & spherical & 50 & - & $\begin{array}{l}\text { Antibacterial activity against Escherichia coli and } \\
\text { Staphylococcus aureus }\end{array}$ & 71 \\
\hline Asteriscus graveolens & spherical & 21,6 & 13.9 & Inhibiting HepG2 cell proliferation & 72 \\
\hline Catharanthus roseus & spherical & 32 & 32.6 & Possible medical applications & 73 \\
\hline Orange peel & spherical & 70 & - & Inhibition of algal blooms & 74 \\
\hline Clausena dentate & spherical & $46-79$ & 72.6 & Insecticidal agent against mosquito vectors & 75 \\
\hline Mountain persimmon & spherical & $4-16$ & - & Antimicrobial activity & 76 \\
\hline Emblica officinalis & & $20-60$ & 61.6 & Antioxidant and antimicrobial agent & 77 \\
\hline Ficus benghalensis & spherical & $45-95$ & - & Photocatalytic degradation of methylene blue dye & 78 \\
\hline Drumstick & spherical & $23-35$ & 44.6 & $\begin{array}{l}\text { Inhibition of Caco-2, HepG2 and Mcl-7 cells } \\
\text { Photocatalytic degradation of sunset yellow dye }\end{array}$ & 79 \\
\hline Guava & spherical & $8-20$ & - & Antibacterial activity & 80 \\
\hline Cacao bean shell & spherical & $1-3$ & - & Antioxidant material & 81 \\
\hline
\end{tabular}

antimutagenic activity against UVB-induced DNA damage of isolated lymphocytes [54].

Selenium nanoparticles have been widely used in biomedical applications due to their antimicrobial effect to control the growth of many pathogenic bacteria and fungi [23, 56, $57,62,64,65,69,71,76,77]$. The antimicrobial activity was evaluated by well diffusion method and calculated as Minimum Inhibitory Concentration (MIC), defined as the lowest concentration of the antimicrobial agent required to inhibit the growth of given microbial species, or as the diameter of inhibition zone expressed in $\mathrm{mm}$. The inhibitory effect of SeNPs on bacteria and fungi may be due to their sorption on the cell wall, penetration through membrane, and entrance to kill the cell [16]. The nanoparticles with a smaller diameter can possibly diffuse the bacteria cell better than the larger ones. Sribenjarat et al. [69] found that SeNPs with size 
range within $21-40 \mathrm{~nm}$ showed a slightly higher inhibition activity than those of 41-50 $\mathrm{mm}$ diameter size. Boroumand et al. [22] evaluated the antibacterial activity of SeNPs on several kinds of gram-positive bacteria (Staphylococcus aureus, Streptococcus epidermidis) and gram-negative bacteria (Escherichia coli, Pseudomonas aeruginosa) and found that they exhibited dose-dependent activity against all tested bacterial strains. Particularly significant effects against the gram-positive bacteria were observed with MIC equals to $125 \mathrm{mg} \mathrm{L}^{-1}$. The MIC value of SeNPs against Proteus $s p$. of $250 \mathrm{mg} \mathrm{L}^{-1}$ was reported [56]. Selenium nanoparticles synthesized using Mountain persimmon leaf extract showed antibacterial effect not only against $S$. aureus bacteria (zone of inhibition $8 \mathrm{~mm})$ and $E$. coli $(7 \mathrm{~mm})$ but also against Aspergillus niger fungi (12 mm) [76]. Likewise, SeNPs synthesized with Aloe vera leaf extract exhibited high antimicrobial activity against pathogenic bacteria and spoilage fungi strains [64].

The surface of medical devices may be coated by SeNPs to prevent biofilm formation. They strongly inhibited the growth of S. aureus bacteria on the surface by $91 \%$ and $73 \%$ after 24 and $72 \mathrm{~h}$ respectively, in comparison to uncoated polycarbonate surfaces [105]. Numerous paper products such as filter paper, air purifying systems, and wrapping paper used in the food industry were also coated by precipitation of selenium nanoparticles [106]. The Se-coated paper showed $90 \%$ of $S$. aureus and S. epidermidi inhibition after $72 \mathrm{~h}$ of treatment. The results for $P$. aeruginosa and $E$. coli growth were about $57 \%$ and $84 \%$, respectively. Thus, the antibacterial and antifungal activity of selenium nanoparticles can be used as an antimicrobial agent. Microbial infection is responsible for many diseases in humans and animals and treatment with antibiotics is not always effective due to their repeated uses resulted in resistance against pathogenic organisms.

SeNPs could be used in the drug delivery system due to easy manipulation in their size and low toxicity [101-103]. They are taken up by cells more efficiently than larger biomolecules. Drugs can either be integrated into the matrix of the particle or attached to its surface. Deng et al. [102-104] developed selenium-layered nanoparticles for oral delivery of mulberry leaf and Pueraria lobata extracts with significant hypoglycemic activities. SeNPs exhibited a slow drug release and good physiological stability in the simulated digestive fluid.

A significant number of countries in the world today are affected by groundwater arsenic contamination, which is linked with a significant increase in the risk of cancers. Prasad and Selvaraj [60] reported the protective effect of biogenic SeNP against As(III)-induced cytotoxic and genotoxic effect on human lymphocytes. The enhancement of cells viability had been noticed when arsenite-treated cells were mixed with selenium nanoparticles preventing the death of lymphocytes. Moreover, the addition of SeNPs into lymphocytes prevented As(III)-induced DNA damage. Selenium nanoparticles have also the ability to decrease the toxicity of other metal ions such $\mathrm{Cd}, \mathrm{Hg}$ or $\mathrm{Cu}$ contained in wastewater or soil [110-113].

Nanoscale selenium is of great interest as an additive to fertilizers $[6,96,114,115]$. The large surface area and small size of the nanomaterials could allow for enhanced interaction and efficient uptake of selenium for crop. The inorganic selenium compounds used as fertilizers are leached along with rains, while organic compounds can be degraded after applying. SeNPs do not dissolve in water and their transition to plants occurs as a result of gradual oxidation of their surface and release as oxides [114]. Mainly, SeNPs act as stimulator and/or stressor increasing antioxidant defence system, improving vegetative growth and nutritional value of plants [114-118]. The eggplant and tomato growth on the soil with the Se nanoparticle addition at a concentration of $10 \mu \mathrm{g} \mathrm{kg}^{-1}$ showed almost twice the plant leaf plate surface area compared to these plants in untreated soil [115]. Zsiros et al. [116] found that SeNPs even at a concentration of $100 \mathrm{mg} \mathrm{L}^{-1}$ exerted no negative effect on the growth of plantlets in tobacco cultures.

Selenium nanoparticles synthesized using extract of plants are also very effective materials for photocatalytic degradation of dyes, due to their high surface to volume ratio $[57,78,79]$. These dyes are largely used as colorants in the common food and pharmaceutical industry. Around 60\% degradation of methylene blue dye was achieved in $40 \mathrm{~min}$ using Fiscus benglalensis leaf extract. Its degradation followed first-order kinetics with the rate constant of $1.3 \mathrm{~min}^{-1}$ [77], while the rate constant of $0.173 \mathrm{~min}^{-1}$ was reported for photodegradation reaction of sunset yellow dye using SeNPs generated with the leaf extract of drumstick tree [80]. Thus, this is an eco-friendly approach for the treatment of wastewater containing dye effluents before being released into an aquatic system.

\section{Conclusion}

Selenium nanoparticles have attracted attention and their synthesis can be potentially useful in various fields. Compared to inorganic and organic selenium species, they display better bioavailability, higher biological activity and lower toxicity. The methods for SeNPs synthesis using plant extracts do not require the use of toxic chemicals, the precursors are easily accessible, inexpensive and do not need any special conditions. That way of synthesis also enables control over the size, shape and stability of nanoparticles. SeNPs synthesized in this manner exhibit particular potential in biomedical applications such as cancer therapy, targeted chemotherapy, molecular diagnosis and drug delivery 
system. They could also be found in suitable applications as efficient antioxidants and antibacterial agents in the food and pharmaceutical industry. A lot of work has been carried out emphasizing numerous applications of SeNPs in the technology and agriculture sectors.

The future prospects of selenium nanoparticles include the development of new fast and environment-friendly methodology for their synthesis to obtain nanomaterial with the corresponding size, shape, and properties for the desired application. It will require a better understanding of physical and chemical properties related to the specific use of SeNPs. Due to their less toxicity to normal cells, it is expected that the drugs based on selenium nanoparticles may be commercially available.

\section{Declarations}

Conflict of interest The authors declare that they have no conflict of interest.

Ethical approval This has not been published elsewhere and is not currently under consideration for publication elsewhere.

Open Access This article is licensed under a Creative Commons Attribution 4.0 International License, which permits use, sharing, adaptation, distribution and reproduction in any medium or format, as long as you give appropriate credit to the original author(s) and the source, provide a link to the Creative Commons licence, and indicate if changes were made. The images or other third party material in this article are included in the article's Creative Commons licence, unless indicated otherwise in a credit line to the material. If material is not included in the article's Creative Commons licence and your intended use is not permitted by statutory regulation or exceeds the permitted use, you will need to obtain permission directly from the copyright holder. To view a copy of this licence, visit http://creativecommons.org/licenses/by/4.0/.

\section{References}

1. Rayman, M.P.: Selenium intake, status, and health: a complex relationship. Hormones 19, 9-14 (2020)

2. Kieliszek, M., Błażejak, S.: Current knowledge on the importance of selenium in food for living organisms: a review. Molecules 21, 609 (2016)

3. Misra, S., Boylan, M., Selvan, A., Spallholz, J.E., Björnstedt, M.: Redox-active selenium compounds from toxicity and cell death to cancer treatment. Nutrients 7, 3536-3556 (2015)

4. Rayman, M.P., Winther, K.H., Pastor-Barriuso, R., Cold, F., Thvilum, M., Stranges, S., Guallar, E., Cold, S.: Effect of longterm selenium supplementation on mortality: results from a multiple-dose, randomised controlled trial. Free Radic. Biol. Med. 127, 46-54 (2018)

5. White, P.J.: Selenium metabolism in plants. Biochim. Biophys. Acta Gen. Subj. 1862, 2333-2342 (2018)

6. El-Ramady, H., Abdalla, N., Taha, H.S., Alshaal, T., El-Henawy, A., Faizy, S.E.D., Shams, M.S., Youssef, S.M., Shalaby, T., Bayoumi, Y., Elhawat, N., Shehata, S., Sztrik, A., Prokisvh, J., Fári, M., Domokos-Szabolcsy, E., Pilon-Smits, E.A., Selmar, D.,
Haneklaus, S., Schnug, E.: Selenium and nano-selenium in plant nutrition. Environ. Chem. Lett. 14, 123-147 (2016)

7. Kumar, A., Prasad, K.S.: Role of nano-selenium in health and environment. J. Biotechnol. 325, 152-163 (2021)

8. Skalickova, S., Milosavljevic, V., Cihalova, K., Horky, P., Richtera, L., Adam, V.: Selenium nanoparticles as a nutritional supplement. Nutrition 33, 83-90 (2017)

9. Khurana, A., Tekula, S., Saifi, M.A., Venkatesh, P., Godugu, C.: Therapeutic applications of selenium nanoparticles. Biomed. Pharmacother. 111, 802-812 (2019)

10. Soumya, M., Shrudhi, D.K.S., Santhija, R., Rajeshkumar, S., Venkat, K.S.: Selenium nanoparticles: a potent chemotherapeutic agent and an elucidation of its mechanism. Colloids Surf. B 170, 280-292 (2018)

11. Chaudhary, S., Umar, A., Mehta, S.K.: Selenium nanoparticles: a overview of recent developments in synthesis, properties and potential applications. Prog. Mater. Sci. 83, 270-329 (2016)

12. Kim, C., Hong, J., Park, J.W.: Synthesis and thermoelectric properties of selenium nanoparticles coated with PEDOT:PSS. Polymers 11, 1052 (2019)

13. Bhattacharjee, A., Bastu, A., Bhattacharya, S.: Selenium nanoparticles are less toxic than inorganic and organic selenium in mice in vivo. Nucleus 62, 259-268 (2019)

14. Quintana, M., Haro-Poniatowski, E., Morales, J., Batina, N.: Synthesis of selenium nanoparticles by pulsed laser ablation. Appl. Surf. Sci. 195, 175-186 (2002)

15. Tzeng, W.Y., Tseng, Y.H., Yeh, T.T., Tu, C.M., Sankar, R., Chen, Y.H., Huang, B.H., Chou, F.C., Luo, C.W.: Selenium nanoparticles prepared by femtosecond laser-induced plasma shock wave. Opt. Express 28, 685 (2020)

16. Van Overschelde, O., Guisbiers, G., Snyders, R.: Green synthesis of selenium nanoparticles by excimer pulsed laser ablation in water. APL Mater 1, 042114 (2013)

17. Qin, J., Qiu, G., Jian, J., Zhou, H., Yang, L., Charnas, A., Zemlyanov, D.Y., Xu, C.Y., Xu, X., Wu, W.: Controlled growth of large-size 2D selenium nanosheet and its electronic and optoelectronic applications. ACS Nano 11, 10222 (2017)

18. Shar, A.H., Lakhan, M.N., Wang, J., Ahmed, M., Alali, K.T., Ahmed, R., Ali, I., Dayo, A.Q.: Facile synthesis and characterization of selenium nanoparticles by the hydrothermal approach. Dig. J. Nanomater. Biostructures 14, 867-872 (2019)

19. Panahi-Kalamuei, M., Mousavi-Kamazani, M., SalavatiNiasari, M., Hosseinpour-Mashkani, S.M.: A simple sonochemical approach for synthesis of selenium nanostructures and investigation of its light harvesting application. Ultrason. Sonochem. 23, 246-256 (2016)

20. El Lateef Gharib, F.A., Zeid, I.M., Ghazi, S.M., Ahmed, E.Z.: The response of cowpea (Vigna unguiculata L.) plants to foliar application of sodium selenate and selenium nanoparticles (SeNPs). J. Nanomater. Mol. Nanotechnol. 8, 4 (2019)

21. Hussein, H.H., Darwesh, O.M., Mekki, B.B.: Environmentally friendly nano-selenium to improve antioxidant system and growth to groundnut cultivars under sandy soil conditions. Biocatalys. Agric. Biotechnol. 18, 101080 (2019)

22. Boroumand, S., Safari, M., Shaabani, E., Shirzah, M., FaridiMaijidi, R.: Selenium nanoparticles: synthesis, characterization and study of their cytotoxicity, antioxidant and antimicrobial activity. Mater. Res. Express 6, 0850d8 (2019)

23. Gangadoo, S., Stanley, D., Hughes, R.J., Moore, R.J., Chapman, J.: The synthesis and characterisation of highly stable and reproducible selenium nanoparticles. Inorg. Nano-Met. Chem. 47, 1568-1576 (2017)

24. Bartosiak, M., Giersz, J., Jankowski, K.: Analytical monitoring of selenium nanoparticles green synthesis using photochemical vapor generation coupled with MIP-OES and UV-Vis spectrophotometry. Microchem. J. 145, 1169-1175 (2019) 
25. Ingole, A.R., Thakare, S.R., Khati, N.T., Wankhade, A.V., Burghate, D.K.: Green synthesis of selenium nanoparticles under ambient condition. Chalcogenide Lett. 7, 485-489 (2010)

26. Nie, T., Wu, H., Wong, K.H., Chen, T.: Facile synthesis of highly uniform selenium nanoparticles using glucose as the reductant and surface decorator to induce cancer cell apoptosis. J. Mater. Chem. B 4, 2351 (2016)

27. Vieira, A.P., Stein, E.M., Andreguetti, D.X., Cebrián-Torrejón, G., Doménech-Carbó, A., Colepicolod, P., Ferreira, A.M.D.: "Sweet chemistry": a green way for obtaining selenium nanoparticles active against cancer cells. J. Braz. Chem. Soc. 28, 2021-2027 (2017)

28. Li, Q., Chen, T., Yang, F., Liu, J., Zheng, W.: Facile and controllable one-step fabrication of selenium nanoparticles assisted by L-cysteine. Mat. Lett. 64, 614-617 (2010)

29. Chen, Z., Shen, Y., Xie, A., Zhu, J., Wu, Z., Huang, F.: L-Cysteine assisted controlled synthesis of selenium nanospheres and nanorods. Cryst. Growth Des. 9, 1327-1333 (2009)

30. Korany, M., Marzook., F, Mahmoud, B., Ahmed, S.A., Ayoub, S.M., Sakr, T.M. : Exhibiting the diagnostic face of selenium nanoparticles as a radio-platform for tumor imaging. Bioor. Chem. 100, 103910 (2020)

31. Hu, T., Li, H., Li, J., Zhao, G., Wu, W., Liu, L., Wang, Q., Guo, Y.: Absorption and bio-transformation of selenium nanoparticles by wheat seedlings (Triticum aestivum L.). Front. Plant Sci. 9, 597 (2018)

32. Guleria, A., Neogy, S., Raorane, B.S., Adhikari, S.: Room temperature ionic liquid assisted rapid synthesis of amorphous $\mathrm{Se}$ nanoparticles: their prolonged stabilization and antioxidant studies. Mater. Chem. Phys. 253, 123369 (2020)

33. Zhang, Y., Wang, J., Zhang, L.: Creation of highly stable selenium nanoparticles capped with hyperbranched polysaccharide in water. Langmuir 26, 17617-17623 (2010)

34. Zhang, S.Y., Zhang, J., Wang, H.Y., Chen, H.Y.: Synthesis of selenium nanoparticles in the presence of polysaccharides. Mater. Lett. 58, 2590-2594 (2004)

35. Chung, S., Zhou, R., Webster, T.J.: Green synthesized BSAcoated selenium nanoparticles inhibit bacterial growth while promoting mammalian cell growth. Int. J. Nanomed. 15, 115-124 (2020)

36. Yu, B., You, P., Song, M., Yua, Y.Z.F., Zheng, W.: A facile and fast synthetic approach to create selenium nanoparticles with diverse shapes and their antioxidation ability. New J. Chem. 40, 1118-1123 (2016)

37. Husen, A., Siddiqi, K.S.: Plants and microbes assisted selenium nanoparticles: characterization and application. J. Nanobiotechnol. 12, 28 (2014)

38. Geoffrion, L.D., Hesabizadeh, T., Medina-Cruz, D., Kusper, M., Taylor, P., Vernet-Crua, A., Chen, J., Ajo, A., Webster, T.J., Guisbiers, G.: Naked selenium nanoparticles for antibacterial and anticancer treatments. ACS Omega 5, 2660-2669 (2020)

39. Sonkusre, P., Cameotra, S.S.: Biogenic selenium nanoparticles inhibit Staphylococcus aureus adherence on different surfaces. Col. Surf. B Biointerfaces 136, 1051-1057 (2015)

40. Srivastava, N., Mukhopadhyay, M.: Biosynthesis and structural characterization of selenium nanoparticles mediated by Zooglea ramigera. Powder Technol. 244, 26-29 (2014)

41. Fernández-Llamosas, H., Castro, L., Blázquez, M.L., Diaz, E., Carmona, M.: Biosynthesis of selenium nanoparticles by Azoarcus sp. CIB. Microb. Cell Factories 15, 109 (2016)

42. Zhang, W., Chen, Z., Liu, H., Zhang, L., Gao, P., Li, D.: Biosynthesis and structural characteristics of selenium nanoparticles by Pseudomonas alcalphilia. Coll. Surf. B Biointerfer. 88, 196-201 (2011)
43. Wadhwani, A.S., Shedbalkar, U.U., Singh, R., Chopade, B.A.: Biogenic selenium nanoparticles: current status and future prospects. Appl. Microbiol. Biotechnol. 100, 2555-2566 (2016)

44. Alam, H., Khatoon, N., Khan, M.A., Hussain, S.A., Saravanan, M., Sardar, M.: Synthesis of selenium nanoparticles using probiotic bacteria Lactobacillus acidophilus and their enhanced antimicrobial activity against resistant bacteria. J. Clust. Sci. 31, 1003-1011 (2020)

45. Zare, B., Babaie, S., Setayesh, N., Shahverdi, A.R.: Isolation and characterization of a fungus for extracellular synthesis of small selenium nanoparticles. Nanomed. J. 1, 13-19 (2013)

46. Joshi, S.M., De Britto, S., Jogaiah, S., Ito, S.: Mycogenic selenium nanoparticles as potential new generation broad spectrum antifungal molecules. Biomolecules 9, 419 (2019)

47. Mosallam, F.M., El-Sayyad, G.S., Fathy, R.M., El-Batal, A.I.: Biomolecules-mediated synthesis of selenium nanoparticles using Aspergillus oryzae fermented Lupin extract and gamma radiation for hindering the growth of some multidrug-resistant bacteria and pathogenic fungi. Microb. Pathogenesis 122, 108$116(2018)$

48. Zhang, H., Zhou, H., Bai, J., Li, Y., Yang, J., Ma, Q., Qu, Y.: Biosynthesis of selenium nanoparticles mediated by fungus Mariannaea sp. HJ and their characterization. Colloids Surf. A 571, 9-16 (2019)

49. Eswayah, A.S., Smith, T.J., Gardiner, P.H.E.: Microbial transformations of selenium species of relevance to bioremediation. Appl. Environ. Microbiol. 82, 4848-4859 (2016)

50. Tugarova, A.V., Kamnev, A.A.: Proteins in microbial synthesis of selenium nanoparticles. Talanta 174, 539-547 (2017)

51. Ojeda, J.J., Merroun, M.L., Tugarova, A.V., Lampis, S., Kamnev, A.A., Gardiner, P.H.E.: Developments in the study and applications of bacterial transformations of selenium species. Crit. Rev. Biotechnol. 40, 1250-1264 (2020)

52. Cui, D., Liang, T., Sun, L., Meng, L., Yang, C., Wang, L., Liang, T., Li, Q.: Green synthesis of selenium nanoparticles with extract of hawthorn fruit induced HepG2 cells apoptosis. Pharm. Biol. 56, 528-534 (2018)

53. Sharma, G., Sharma, A.R., Bhavesh, R., Park, J., Ganbold, B., Nam, J.S., Lee, S.S.: Biomolecule-mediated synthesis of selenium nanoparticles using dried Vitis vinifera (raisin) extract. Molecules 19, 2761-2770 (2014)

54. Prasad, K.S., Patel, H., Patel, T., Patel, K., Selvaraj, K.: Biosynthesis of Se nanoparticles and its effect on UV-induces DNA damage. Colloids Surf. B: Biointerferences 103, 261-266 (2013)

55. Deepa, B., Ganesan, V.: Biogenic synthesis and characterization of selenium nanoparticles using the flower of Bougainvillea spectabilis willd. IJSR 4, 690-695 (2015)

56. Menon, S., Shrudhi Devi, K.S., Agarval, H., Shanmugam, V.K.: Efficacy of biogenic selenium nanoparticles from an extract of ginger towards evaluation on anti-microbial and anti-oxidant activities. Colloids Interface Sci. Commun. 29, 1-8 (2019)

57. Alagesan, V., Venugopal, S.: Green synthesis of selenium nanoparticles using leaves extract of Withania somnifera and its biological applications and photocatalytic activities. BioNanoScience 9, 105-116 (2019)

58. Ramamurthy, C.H., Sampah, K.S., Arunkumar, P., Kumar, M.S., Sujatha, V., Premkumar, K., Thirunavakkarasu, C.: Green synthesis and characterization of selenium nanoparticles and its augmented cytotoxicity with doxorubicin on cancer cells. Bioprocess Biosys. Eng. 36, 1131-1139 (2013)

59. Anu, K., Devanesan, S., Prasanth, R., AlSalhi, M.S., Ajithkumar, S., Singaravelu, G.: Biogenesis of selenium nanoparticles and their anti-leukemia activity. J. King Saud. Univ. Sci. 32, 25202526 (2020) 
60. Prasad, K.S., Selvaraj, K.: Biogenic synthesis of selenium nanoparticles and their effect on As(III)-induced toxicity on human lymphocytes. Biol. Trace Elem. Res. 157, 275-283 (2014)

61. Sivakumar, C., Jeganathan, K.: In-vitro cytotoxicity of java tea mediated selenium nanoballs against L6 cell lines. J. Drug Deliv. Ther. 8, 195-200 (2018)

62. Kirupagaran, R., Saritha, A., Bhuvaneswari, S.: Green synthesis of selenium nanoparticles from leaf ad steam extract of Leucas lavandulifolia Sm. and their application. J. Nanosci. Technol. 2, 224-226 (2016)

63. Vyas, J., Rana, S.: Antioxidant activity and biogenic synthesis of selenium nanoparticles using the leaf extract of Aloe vera. Inter. J. Curr. Pharm. Res. 9, 147-152 (2017)

64. Fardsadegh, B., Jafarizadeh-Malmiri, H.: Aloe vera leaf extract mediated green synthesis of selenium nanoparticles and assessment of their in vitro antimicrobial activity against spoilage fungi and pathogenic bacteria strains. Green Process Synth. 8, 399-407 (2019)

65. Vyas, J., Rana, S.: Synthesis of selenium nanoparticles using Allium sativum extract and analysis of their antimicrobial property against gram positive bacteria. Pharm. Innov. J. 7, 262-266 (2018)

66. Ezhuthupurakkal, P.B., Polaki, L.R., Suyavaran, A., Subastri, A., Sujatha, V., Thirunavukkarasu, C.: Selenium nanoparticles synthesized in aqueous extract of Allium sativum perturbs the structural integrity of Calf thymus DNA trough intercalation an groove binding. Mat. Sci. Eng. C 74, 597-608 (2017)

67. Vyas, J., Rana, S.: Antioxidant activity and green synthesis of selenium nanoparticles using Allium sativum extract. Inter. J. Phytomed. 9, 634-641 (2017)

68. Anu, K., Singaravelu, G., Murugan, K., Benelli, G.: Greensynthesis of selenium nanoparticles using garlic cloves (Allium sativum): biophysical characterization and cytotoxicity on Vero cells. J. Clust. Sci. 28, 551-563 (2017)

69. Sribenjarat, P., Jirakanjanakit, N., Jirasripogpun, K.: Selenium nanoparticles biosynthesized by garlic extract as antimicrobial agent. SEHS 14, 22-31 (2020)

70. Sheikhlou, K., Allahyari, S., Sabouri, S., Najian, Y., Jafarizadeh-Malmiri, H.: Walnut leaf extract-based green synthesis of selenium nanoparticles via microwave irradiation and their characteristics assessment. Open Agric. 5, 227-235 (2020)

71. Fardsadegh, B., Vaghari, H., Mohammad-Jafari, R., Najian, Y., Jafarizadeh-Malmiri, H.: Biosynthesis, characterization and antimicrobial activities assessment of fabricated selenium nanoparticles using Pelargonium zonale leaf extract. Green Process Synth. 8, 191-198 (2019)

72. Zeebaree, S.Y.S., Zeebaree, A.Y.S., Zebari, O.I.H.: Diagnosis of the multiple effect of selenium nanoparticles decorated by Asteriscus graveolens components in inhibiting HepG2 cell proliferation. Sustain. Chem. Pharm. 15, 100210 (2020)

73. Deepa, B., Ganesan, V.: Bioinspiredsynthesis of selenium nanoparticles using flowers of Catharanthus roseus (L.) G. Don. and Peltophorum pterocarpum (DC.) Backer ex Heyne-a comparison. Int. J. ChemTech. Res. 7, 725-733 (2015)

74. Sasidharan, S., Sowmiya, R., Balakrishnaraja, R.: Biosynthesis of selenium nanoparticles using Citrus reticulata peel extract. World J. Pharm. Res. 4, 1322-1330 (2014)

75. Sowndarya, P., Ramkumar, G., Shivakumar, M.S.: Green synthesis of selenium nanoparticles conjugated Clausena dentata plant leaf extract and their insecticidal potential against mosquito vectors. Artif. Cells Nanomed. Biotechnol. 45, 14901495 (2017)

76. Kokila, K., Elavarasan, N., Sujatha, V.: Diospyros montana leaf extract-mediated synthesis of selenium nanoparticles and their biological applications. New J. Chem. 41, 7481-7490 (2017)
77. Gunti, L., Dass, R.S., Kalagatur, N.K.: Phytofabrication of selenium nanoparticles from Emblica officinalis fruit extract and exploring its biopotential applications: antioxidant, antimicrobial, and biocompatibility. Front. Microbiol. 10, 931 (2019)

78. Abu-Elghait, M., Hasanin, M., Hashem, A.H., Salem, S.S.: Ecofriendly novel synthesis of tertiary composite based on cellulose and myco-synthesized selenium nanoparticles: Characterization, antibiofilm and biocompatibility. Inter. J. Biol. Macrom. 175, 294-303 (2021)

79. Tripathi, R.M., Hameed, P., Rao, R.P., Shrivastava, N., Mittal, J., Mohapatra, S.: Biosynthesis of highly stable fluorescent selenium nanoparticles and the evaluation of their photocatalytic degradation of dye. BioNanoScience 10, 389-396 (2020)

80. Hassanien, R., Abed-Elmageed, A.A., Husein, D.Z.: Eco-friendly approach to synthesize selenium nanoparticles: photocatalytic degradation of sunset yellow azo dye and anticancer activity. ChemistrySelect 4, 9018-9026 (2020)

81. Alam, H., Khatoon, N., Raza, M., Ghosh, P.C., Sardar, M.: Synthesis and characterization of nano selenium using plant biomolecules and their potential applications. BioNanoScience 9, 96-104 (2019)

82. Mellinas, C., Jiménez, A., Garrigós, M.C.: Microwave-assisted green synthesis and antioxidant activity of selenium nanoparticles using Theobroma cacao L. bean shell extract. Molecules 24, 4048 (2019)

83. McClements, J., McClements, D.J.: Standardization of nanoparticle characterization: methods for testing properties, stability, and functionality of edible nanoparticles. Crit. Rev. Food Sci. Nutr. 56, 1334-1362 (2016)

84. Tugarova, A.V., Mamchenkova, P.V., Khanadeev, V.A., Kamnev, A.A.: Selenite reduction by the rhizobacterium Azospirillum brasilense, synthesis of extracellular selenium nanoparticles and their characterisation. New Biotechnol. 58, 17-24 (2020)

85. Bhattacharjee, S.: DLS and zeta potential - What they are and what they are not? J. Control Release 235, 337-351 (2016)

86. Zhang, S.Y., Zhang, J., Wang, H.Y., Hong-Yuan Chen, H.Y.: Synthesis of selenium nanoparticles in the presence of polysaccharides. Mater. Lett. 58, 2590-2594 (2004)

87. Zhao, G., Wu, X., Chen, P., Zhang, L., Yang, C.S., Zhan, J.: Selenium nanoparticles are more efficient than sodium selenite in producing reactive oxygen species and hyper-accumulation of selenium nanoparticles in cancer cells generates potent therapeutic effects. Free Radic. Biol. Med. 126, 55-66 (2018)

88. Sentkowska, A., Pyrzynska, K.: Investigation of antioxidant activity of selenium compounds and their mixtures with tea polyphenols. Mol. Biol. Rep. 46, 3019-3024 (2019)

89. Rahmanto, A.S., Davies, M.J.: Selenium-containing amino acids as direct and indirect antioxidants. Life 64, 863-871 (2012)

90. Kondaparrthi, P., Flora, S.J.S., Naqvi, S.: Selenium nanoparticles: an insight on its pro-oxidant and antioxidant properties. Front. Nanosci. Nanotechnol. 6, 1-5 (2019)

91. Dumore, N.D., Mukhopadhyay, M.: Antioxidant of aqueous selenium nanoparticles (ASeNPs) and its catalysts activity for 1,1'-diphenyl-2-picrylhydrazyl (DPPH) reduction. J. Mol. Struct. 1205, 127637 (2020)

92. Xiao, F., Xu, T., Lu, B., Liu, R.: Guidelines for antioxidant assays for food components. Food Front. 1, 60-69 (2020)

93. Apak, R., Gorinstein, S., Böhm, V., Schaich, K.M., Ôzyürek, M., Güçlü, K.: Methods of measurement and evaluation of natural antioxidant capacity/activity (IUPAC Technical Report). Pure Appl. Chem. 85, 957-998 (2013)

94. Wang, Y.Y., Qiu, W.Y., Sun, L., Ding, Z.C., Ya, J.K.: Preparation, characterization, and antioxidant capacities of selenium nanoparticles stabilized using polysaccharide-protein complexes from Corbicula fluminea. Food Biosence 26, 177-184 (2018) 
95. Shang, Y., Hasan, K., Ahammed, G.J., Li, M., Yin, H., Zhou, J.: Application of nanotechnology in plant growth and crop protection: a review. Molecules 24, 2558 (2019)

96. Kumar, P., Mahajan, P., Kaur, R, Gautam, S.: Nanotechnology and its challenge in the food sector: a review. Mater. Today Chem. 17, 100332 (2020)

97. Marquez, V.G., Moreno, A.M., Mendoza, A.B., Macias, J.M.: Ionic selenium and nanoselenium as biofortifiers and stimulators of plant metabolism. Agronomy 10, 1399 (2020)

98. Nayak, V., Singh, K.R.B., Singh, A.K., Singh, R.P.: Potentialities of selenium nanoparticles in biomedical science. New J. Chem. 45, 2849-2878 (2021)

99. Ikram, M., Javed, B., Raja, N.I., Mashwani, Z.U.R.: Biomedical potential of plant-based selenium nanoparticles: a comprehensive review on therapeutic and mechanistic aspects. Inter. J. Nanomed. 16, 249-268 (2021)

100. Wallenberg, M., Misra, S., Björnsted, M.: Selenium cytotoxicity in cancer. Basic Clin. Pharmacol. Toxicol. 114, 377-438 (2014)

101. Kuršvietiene, L., Mongirdienė, A., Bernatonienè, J., Šulinskienė, J., Štanevičienè, I.: Selenium anticancer properties and impact on cellular redox status. Antioxidants 9, 80 (2020)

102. Tan, H.W., Mo, H.Y., Lau, A.T.Y., Xu, Y.M.: Selenium species: current status and potentials in cancer prevention and therapy. Int. J. Mol. Sci. 20, 75 (2019)

103. Sakr, T.M., Korany, M., Katti, K.V.: Selenium nanomaterials in biomedicine - An overview of new opportunities in nanomedicine of selenium. J Drug Deliv. Sci. Technol. 46, 223-233 (2018)

104. Huang, Y., He, L., Liu, W., Fan, C., Zheng, W., Wong, Y.S., Chen, T.: Selective cellular uptake and induction of apoptosis of cancer-targeted selenium nanoparticles. Biomaterials 34, 7106-7116 (2013)

105. Wang, Q., Webster, T.J.: Nanostructured selenium for preventing biofilm formation on medical devices. J. Biomed. Mat. Res. Part A 100, 3205-3210 (2012)

106. Wang, Q., Larese-Casanova, P., Webster, T.: Inhibition of various gram-positive and gram-negative bacteria growth on selenium nanoparticles coated paper towels. Int. J. Nanomed. 10, 2885 (2015)

107. Deng, W., Wang, H., Wu, B., Zhang, X.: Selenium-layered nanoparticles serving for oral delivery of phytomedicines with hypoglycaemic activity to synergistically potentiate the antidiabetic effect. Acta Pharm. Sin. B 9, 74-86 (2019)

108. El-Borady, O.M., Othman, M.S., Atallah, H.H., Moneim, A.E.A.: Hypoglycemic potential of selenium nanoparticles capped with polyvinyl-pyrrolidone in streptozotocin-induced experimental diabetes in rats. Heliyon 6, e04045 (2020)
109. Ahmad, R., Srivastawa, S., Ghost, S., Khare, S.K.: Phytochemical delivery through nanocarriers: a review. Colloids Surf. B 197 , 111389 (2021)

110. Jain, R., Dominic, D., Jordan, N., Rene, E.R., Weiss, S., van Hullebusch, E.D., Hübner, R., Lens, P.N.L.: Preferential adsorption of $\mathrm{Cu}$ in a multi-metal mixture onto biogenic elemental selenium nanoparticles. Chem. Eng. J. 284, 917-925 (2016)

111. Yuan, F., Song, C., Sun, X., Tan, L., Wang, Y., Wang, S.: Adsorption of $\mathrm{Cd}$ (II) from aqueous solution by biogenic selenium nanoparticles. RCS Adv. 6, 15201-15209 (2016)

112. Wang, X., Zhang, D., Pan, X., Fahad, D.J., Al-Misned, A., Mortuza, M.G., Gadd, G.M.: Aerobic and anaerobic biosynthesis of nano-selenium for remediation of mercury-contaminated soil Chemosphere 170, 266-273 (2017)

113. Yang, J., Hou, B., Wang, J., Tian, B., Bi, J., Wang, N., Li, X., Huang, X.: Nanomaterials for the removal of heavy metals from wastewater. Nanomaterials 9, 424 (2019)

114. Gudkov, S.V., Shafeev, G.A., Glinushkin, A.P., Shkirin, A.V., Barmina, E.V., Rakov, I., Simakin, A.V., Kislov, A.V., Astashev, M.E., Vodeneev, V.A., Kalinitchenko, V.P.: Production and use of selenium nanoparticles as fertilizers. ACS Omega 5, 1776717774 (2020)

115. El-Ramady, H., Faizy, E.D.S., Abdalla, N., Taha, H., DomokosSzabolcsy, E., Fari, M., Elsakhawy, T., El-Dein Omara, A., Shalaby, T., Bayoumi, Y., Shehata, S., Geilfus, C.M., Brevik, E.C.: Selenium and nano-selenium biofortification for human health: opportunities and challenges. Soil Syst. 4, 57 (2020)

116. Zsiros, O., Nagy, V., Párducz, Á., Nagy, G., Ünnep, R., El-Ramady, H., Prokisch, J., Lisztes-Szabó, Z., Fári, M., Csajbók, J., Zita, S., Garab, G., Domokos-Szabolcsy, E.: Effect of selenate and red Se-nanoparticles on the photosynthetic apparatus of Nicotiana tabacum. Photosynth. Res. 139, 449-460 (2019)

117. El Lataef Gharlb, F., Zeid, I.M., Ghazi, S.M., Abmed, E.Z.: The response of cowpea (Vigna unguiculata $\mathrm{L}$ ) plants to foliar application of sodium selenite and selenium nanoparticles (SeNPs). J. Nanomater. Mol. Nanotechnol. 8, 1000272 (2018)

118. Hussein, H.A., Darwesh, O.M., Mekki, B.B.: Environmentally friendly nano-selenium to improve antioxidant system and growth of groundnut cultivars under sandy soil conditions. Biocatal Agric Biotechnol 18, 101080 (2019)

Publisher's Note Springer Nature remains neutral with regard to jurisdictional claims in published maps and institutional affiliations. 